\title{
Hundertwasser's theory and its relation to the Slow Fashion movement
}

Vanessa Mazzocchi Koppe

Master's Degree, Universidade do Estado de Santa Catarina $\underline{\text { lattes }}$

Neide Köhler Schulte

PhD, Universidade do Estado de Santa Catarina Orcid: 0000-0001-5690-5819/ lattes

Sandra Regina Rech

PhD, Universidade do Estado de Santa Catarina Orcid: 0000-0002-0062-6914/ lattes

Icléia Silveira

PhD, Universidade do Estado de Santa Catarina Orcid: 0000-0003-4493-9768/ lattes 


\title{
Hundertwasser's theory and its relation to the Slow fashion movement
}

\begin{abstract}
This article proposes to develop a relationship between behavioral tendencies, the work of Hundertwasser's artist and the Slow fashion movement, and understand better how fashion influences personal attitudes and how it has contributed to huge changes of the current market. Demonstrate through the behavioral analysis that each identity is built from the consumes and way of life.
\end{abstract}

Keywords: fashion design. Trend. Hundertwasser. 


\title{
A teoria de Hundertwasser e sua relação com o movimento Slow fashion
}

\begin{abstract}
RESUMO
Este artigo se propõe a desenvolver uma relação entre tendências de comportamento, a obra do artista Hundertwasser e o movimento Slow fashion, e compreender melhor como a moda influencia nas atitudes pessoais e de que forma ela tem contribuído para as grandes mudanças do mercado atual. Através de uma análise comportamental, demonstrar que a identidade de cada um se constrói a partir do que ele consome e seu modo de vida.
\end{abstract}

Palavras-chave: design de moda. Tendência. Hundertwasser. 


\title{
La teoría de Hundertwasser y su relación con el movimiento Slow fashion
}

\begin{abstract}
O
Este artículo se propone desarrollar una relación entre tendencias de comportamiento, la obra del artista Hundertwasser $y$ el movimiento Slow fashion, $y$ entender mejor cómo la moda influye en las actitudes personales $y$ cómo ha contribuido a los grandes cambios del mercado actual. A través de un análisis conductual, demostrar que la identidad de cada uno se construye a partir de lo que él consume y su modo de vida.
\end{abstract}

Palabras clave: diseño de moda. Tendencia. Hundertwasser. 


\section{INTRODUCTION}

Fashion is one of the social and cultural phenomena of the contemporary world that mobilizes and influences people. Its contribution to the formation of each individual's identity is direct because the fashion system is responsible for driving trends, concepts, and ideas. When talking about trends, there is a direct reference to fashion. In general, a tendency (trend) is an inclination toward something, a force of attraction. In fashion trends are predictions, speculations obtained through behavioral and consumption surveys. Campos (2013) states that the study of trends involves researching the present and outlining plans, visions, and conjunctures about the future.

We live in a world where everything and everyone is constantly changing. This change is linked to the new rhythm of life. Consumers are becoming increasingly aware of ethical issues, and companies that don't adapt can stay out of the new generation's consumption demands.

According to Berlim (2012, p. 88), "in recent years society has come to better understand the concepts of 'sustainable' and creators, in turn, have come to understand that nothing can be $100 \%$ sustainable and that any practice of sustainability is welcome in the production of a product". Based on this premise, the present work proposes to establish a relation between the Hundertwasser Five Skin Theory and the Slow Fashion movement, through a behavioral perspective.

Although consumption is inevitable, besides being important for the productive chain, we can think fashion through a sustainable perspective. This is one of the most significant ways for changes in today's society scenario. The fashion and clothing industry generates many jobs on the world stage, but on the other hand, it is also an industry that 
generates a lot of waste. The scenario of sustainability encompasses not only an evolution in the productive process of the fashion industry but also the understanding of a new lifestyle's consumer, engaged with the problems of humanity and concerned with ethical values through their choices of consumption.

In Hundertwasser's work - an Austrian artist known for vividly recommending sustainability - he argues that consumerism distances man from his true goals: well-being, enjoying and good doing to the environment. Hundertwasser constituted a chain that he called trans-automatism, a kind of surrealism centered on the observer's personal view - where we can identify two major world trends - identity and sustainability.

Restany (2003) says that for Hundertwasser, the human body consists of five skins, where the individual is created by layers from his dermis to the earth, where he lives and denominates them as follows: The Epidermis, The Clothing, The House, the Social Identity and the Global and Ecological Environment. And this is one of his theories dealt with in this study.

The choice of the theme came through the interest in researching trends and behaviors, since each human being is unique and has its identity, and his personal tastes arise from lived experiences. In addition, understanding better how fashion influences personal attitudes and styles through clothing is of great importance in the face of major changes in the current marketplace and as Lee (2009) states, "[...] sustainability can be a good business ". Thus, to develop this study to highlight the relevance of sustainability in fashion has great importance for society.

From the sustainable point of view, gathering information and developing an analysis of human behavior, through the 
movement of slow fashion, ethical and unified movement that promotes a reduction alternative to mass production, is a way of referring to ecological fashion, which comes highlighting as one of the major behavioral changes, as well as facilitating the transition process for consumer awareness and sustainable practices of designers, who need to modify design processes, including sustainable DNA from the start of their projects.

The approach of this research will be qualitative based on the bibliographical retrieval, searching for informative data about the subject, through descriptive research.

\section{TREND}

Through the study of trends, we can obtain relevant information about social behavior, becoming an important tool to identify and analyze the evolution of the consumer and their mentality. The term tendency, according to Caldas (2004, p. 23), comes from the Latin tendentia, noun of the verb tendere, which means "to tend to", "to lean toward" or "attracted by", that is, it is a slope or preference for a certain thing. Thus, trends work as a representation of the future, of scenarios that tend to happen.

It can be understood as a phenomenon that is always defined by an objective or a purpose, which exerts a force of attraction on the one who undergoes the tendency; it expresses movement and comprehensiveness; is something finite (in the sense that it is directed towards an end) and, at the same time, it is not $100 \%$ certain that it reaches its goal; is a drive that seeks to satisfy needs (originated by desires), and finally, it is something that can assume partial and pejorative airs (CALDAS, 2004, p. 26). 
Caldas (2004, p. 43) believes that the concept of a trend has been constructed over time, responding to a specific type of sensibility that was revealed with modernity with its cult of the new, consecrated in postmodernity where behavioral liquidity was in vogue.

Trends could be described in the sociological context, according to Erner (2015, p. 12), as "a behavior adopted temporarily by a substantial part of a social group when this behavior is perceived as socially appropriate for the time and situation". Still, for this author, the sociology of tendencies would seek to give an answer to the transformation of collective taste, which leads us to realize that the focus of trends lies in the changes of taste and in the understanding of how they propagate.

In the process of identifying trends, it is essential to build the best possible understanding of the spirit of the time and the moment in which we live. It becomes necessary to know the "Zeitgeist". For Vejlgaard (2008), through the process of identification, observation, and analysis, clues can be drawn that help identifying patterns of behavior, and that lead to the recognition of one or several trends and their potential for growth. With trend studies, by observing patterns of behavior that lead to the identification of trends, innovation can be generated that, applied to business strategies, meets what the consumer is receptive at a given moment.

The trends analysis can be considered prospecting when talking about thinking about the future. For Vejlgaard (2008) the changes in style and taste have been developing for several centuries, and have reached an exponential pace in the first decades of the twenty-first century. For Caldas (2017) it is practically unanimous to point out individualism with a definitive trait of ethos in the 21st century. Consumer 
motivations have changed, especially those that pertain to individual choices.

The notion of well-being and quality of life, shared by the majority, would assume personal meanings, having a common denominator the central perception of the individuals with the care of themselves, or wellness, as that hypertrophied sphere of the lifestyle would come to be known (CALDAS, 2017, p. 81).

Starting from the idea that there are currently different processes of change in society and that not all of them occur in the same way, many scholars and sociologists' study how people adapt to new ideas and knowledge through new behaviors. From this premise, the present article intends to understand the behavior of the slow fashion, through a reading of the study of Hundertwasser and the theory of the five skins, the subject approached in the next topic.

\section{THE ARTIST OF 5 (FIVE) SKINS}

Friedensreich Hundertwasser, born in Vienna on December 15,1928 , elaborated his work based on the reconstruction of the way of seeing life. Became known as a "doctor of architecture", for strongly recommending sustainability and for hating the straight line, and believing that the integration of sustainable elements can lead man to achieve a more peaceful and happy life.

In 1972, Hundertwasser published the manifesto "Your Window Right - Your Tree Duty" and spectacularly intervenes in a television broadcast in favor of a better quality habitat: roofs covered with vegetation and individual arrangement of the facades (RESTANY, 2003, p. 8).

According to Restany (2003), Hundertwasser argues that consumerism distances man from his true objectives: well- 
being, good use and good for the environment. Thus, he constructed a theory in which he supports that the individual is created in layers from his dermis to the earth, where he lives. And it is called the 5 (five) skins of the human: The Epidermis, The Clothing, The House, Social Identity and the Global and Ecological Environment. Figure 1 shows the spiral created by Hundertwasser.

Figure 1. The Hundertwasser.Spiral

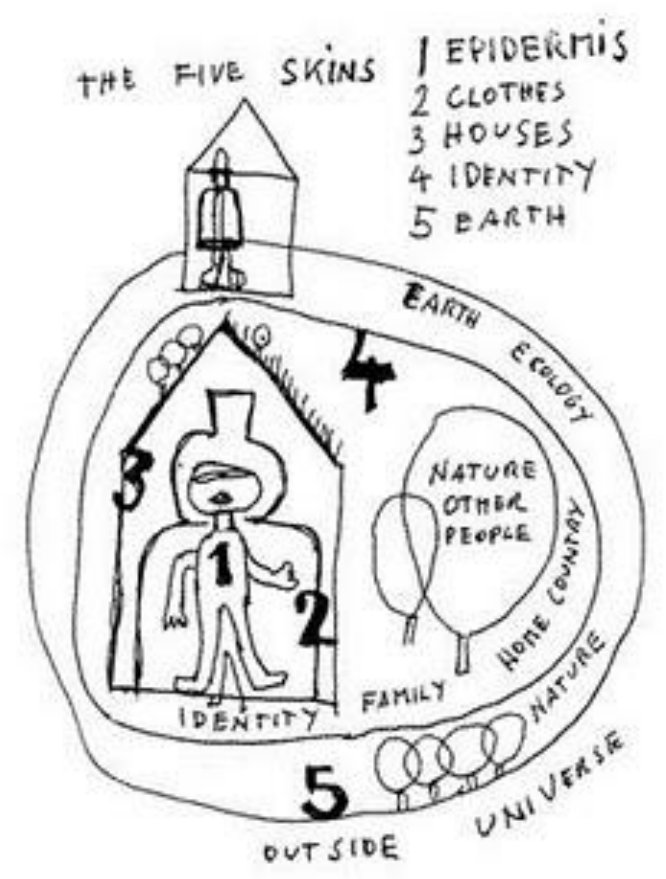

Source: http://opcao-criativa.blogspot.com.br/

\subsection{The first skin — the epidermis}

The first skin consists the involvement of the human being associated with nature and the organic world, a return to predecessor principles and formators of the human condition, the recognition of our senses, feelings and their various meanings. For Nunes (2008), the epidermis consists of the Self. As a cover, sensitive surface, integral of the human body. 
The epidermis transmits the basic needs of the human being: from physiological to sexuality and death.

Oliveira (2008) comments that the first skin is that of learning, of the earthly feeling of a whole and sustainable body, vital energy force. The author also states that Hundertwasser and his multi-furred Self install the spiral initiated in itself, and by imagining in this way the meaning of the first relation begins within and with the earthly dimension of our body as a process of discovery of our organic and energetic encounters with the earthly dimension of nature.

Hundertwasser's spiral is Austrian, Jugendstil, Baroque, Roman, Celtic, Coptic, Mesopotamian, Maori, religious: this is why it also draws us 'naturally' in the direction of the infinite perspective of the different unconscious ones that occupy the soul (RESTANY, 2003, p. 1718).

For Hundertwasser, the creative power of man refers to the existence of his nature, his freedom. Man must be naked, according to Figure 2, open to creation and free from the demands and manipulations of people.

Figure 2. Hundertwasser during the bare speech against rationalism in architecture (1967).

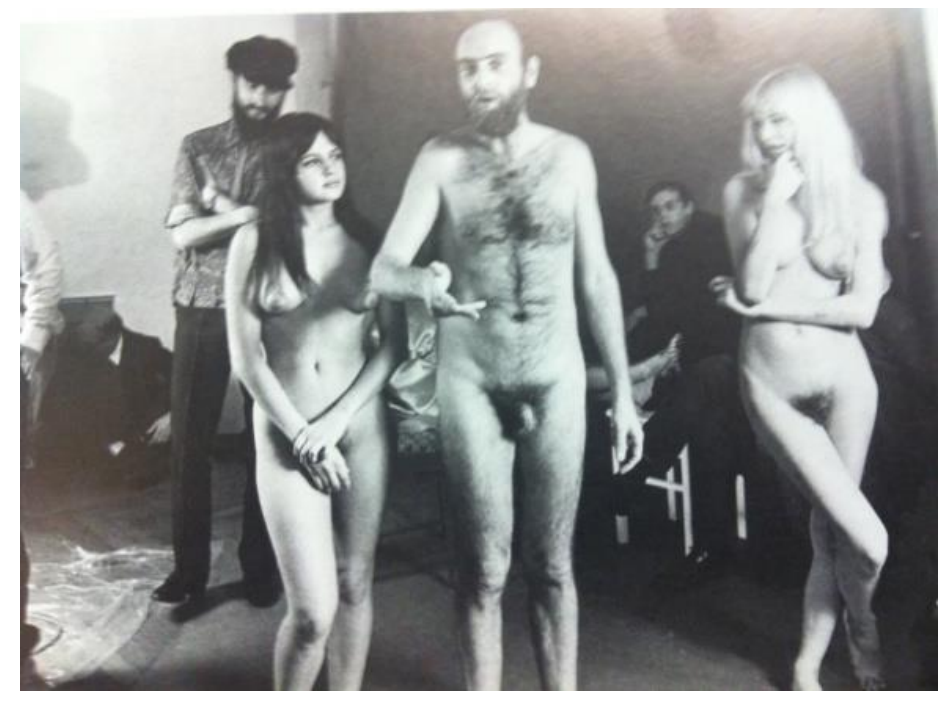

Source: http://www.flutuante.wordpress.com 
For the artist, to show his beauty in the aspects of more sublime intensities is a way of conducting an impulsive and spontaneous testimony of each individual. According to Restany (2003, p. 17), Hundertwasser believed that the grace of beauty was the secret of creativity in the depths of the human soul.

\subsection{The second skin - the clothing}

Hundertwasser made his own clothes. He sewed coats, hats, and shoes. The artist began to make his clothes when he became aware of his second skin. Figure 3 shows the shoes made by the artist himself.

Figure 3. Hundertwasser with winter and summer shoes made by himself, Paris 1950.

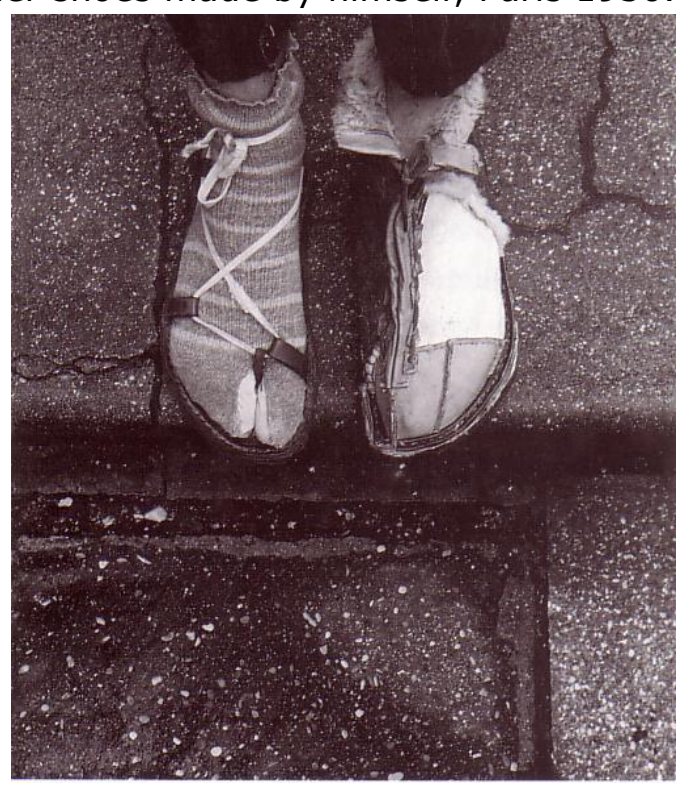

Source: http://brasiliaconcreta.com.br/

More than a simple cloth lining the body, clothing is the visibility of man in the world. Hundertwasser opposes the production and manufacture of pieces in series, encouraged 
by globalization and consumer customs because they mechanize and equate man when they should attest to his individuality through clothing. In this system of production, all are affected by evils, as far as the second skin is concerned: uniformity, symmetry and the tyranny of fashion (RESTANY, 2003).

The second skin is ephemeral, as is modern culture, and can easily be modified. Clothing, like body extensions, shows that on one side is the person and on the other the "impression" that he wishes to pass. However, it is through the body that one perceives and experiences the universe that surrounds him. One lives in a society where the body is formed "artificially" and at the mercy of fashion. So, "on the skin of each individual as a new set of texts, the second skin, in its multiple manifestations, allows the guidance and orientation that refers to the individual position of the subject before the collective, the private in relation to the public" (CASTILHO, 2004, p. 73).

The uniformity of the anonymity of clothing translates into the man in the renunciation of individualism, the pride of using a second creative skin, original and different from the others (RESTANY, 2003). Clothing no longer merely conceals, but reveals the subjectivity of the human being to the outer universe, at the same time as it favors the interiorization of the subject that makes use of it. It has a political, social, and sociological function by presenting our individual identity to the outside world (NUNES, 2008).

Both in his paintings and in his clothes and architecture, Hundertwasser values the color, denying gray color and monochromatic harmony. His rule of beauty applies to the entire creative universe surrounding the man. A vital component of beauty, it grants color to a sacred condition. The second skin is the power of affinity that the clothing exerts 
on the person. So, whether or not to be fashionable depends on the "package" that goes around the body.

\subsection{The third skin - the house}

The house, the ceiling, the walls, the windows, and the doors, entrances, and exits, welcome and shelter the human, and suggest the third skin. The abode of the immense body builds and vividly takes its colors and forms into the home of life. The house where the man resides and fulfills his daily obligations is the place erected where he spends most of the hours. For Hundertwasser, "a house must interact directly with nature, must be organic, alive and in a state of continuous change" (SILVA, 2013, p. 27).

Nunes (2008) describes that the "Window Right" advocates the execution of individuality and the efficiency of the invention in our own circles. It gives us the freedom to adorn the facade around the windows of our homes according to our personal yearnings and interests. "Every great simple image reveals a state of the soul. The house, even more so than the landscape, is "a state of soul". Even reproduced in its external aspect, it speaks of an intimacy "(BACHELARD, 1993, apud NUNES, 2008, p. 28).

The "Tree Duty" is the concern of the human relationship with nature. Nunes (2008) comments on the importance of nature being brought to constructions created by society. Hundertwasser elaborated this project to remind everyone that the loss of contact with nature entails disorientation to humanity. Figure 4 contemplates the tree-tenant project. 
Figure 4. The tree-tenant project, Via Manzoni, Milan, 1973.

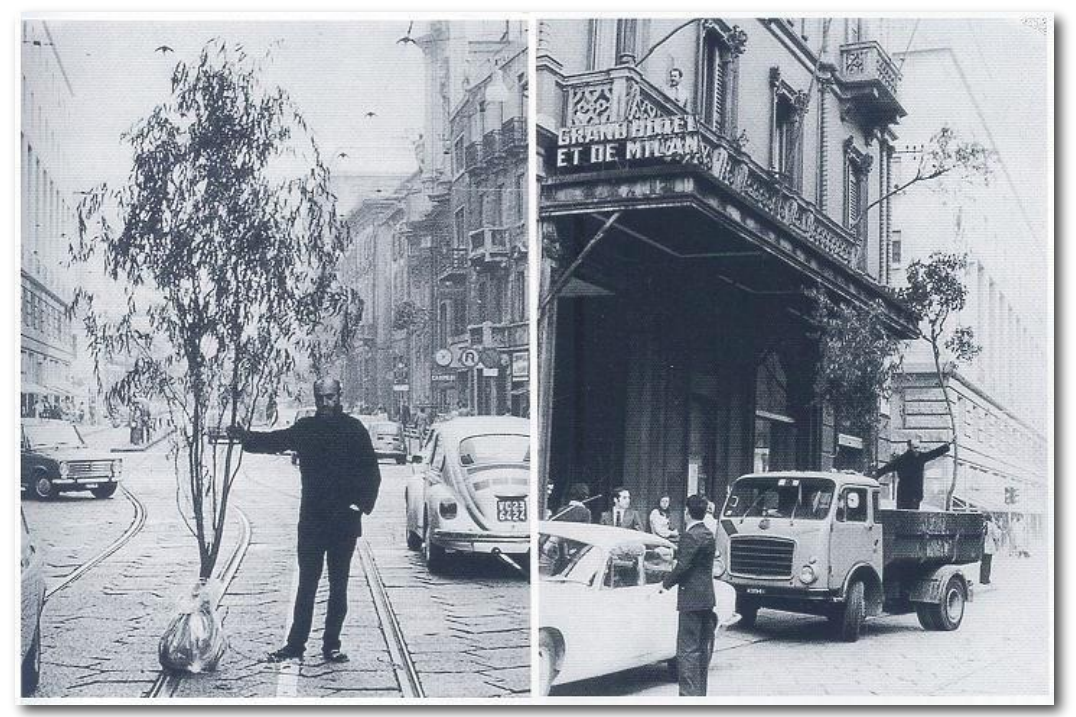

Source: RESTANY, 1999.

Humanity must, after having exercised their destructive nature for so long, establish a peace treaty with nature. For the painter when we let nature repaint the walls, they become human and we can return to live.

\subsection{The fourth skin - social identity}

Hundertwasser's fourth skin is directly related to the family and to the social-cultural universe. Thus, his fourth skin has a great connection with the emotional issues of objects that interfere with or influence the identity of the user man.

The fourth skin doesn 't cease at the family's level, natural or acquired, but extends to the social environment, "to all associative groups that manage the life of a community" (RESTANY, 2003, p. 65). According to Nunes (2008, p. 42) "Hundertwasser has sympathy for the identity given by a nation to its people." The fourth skin, that is, the social 
environment is organized in the set of associative groups that give life to a collective.

Nunes (2008) also shows that in order to achieve universal harmony, the artist defends the proposal of a pacifist aesthetic-naturist society. That is, he believes that beauty projects peace; so that the citizen of "happy spaces", offered by its natural architecture, enjoys happiness with all that coexists. The same affirms the national force in relation to the citizens and is dedicated to distinguish and affirm the identity of a people: the flag, postage stamps, among other symbols that identify them as a nation.

The most mobile brand of national identity created by Hundertwasser "is constituted in its code of moral practice: the images represented are full of beauty and convey peace" (NUNES, 2008, p. 44). The artist puts his imagination into practice in creating coins, but with no commercial value recognized. In addition to the coins, it also produces a series of "Time drops" watches and wristwatches, phone card forms and casino chips.

Restany (2003), in describing the Theory of the Five (5) skins of the human, classifies the artist as a loving man, judging him as a "painter" of a painting to live even better. "To live always better" would be his fifth and last skin - linked to humanity, nature and the environment.

\subsection{The fifth skin - the global environment - ecology and humanity}

For Hundertwasser, we all belong to a huge network of knowledge and practice of other ways of acting and living. Oliveira (2012) states that in the hundertwasserian logic all practitioners share the same skin, transferring reasons to rethink their limits. His way of life begins to confront the 
dictatorship of reason and symmetry because now it deforms and becomes irregular on all sides, following the flow, the event, the creativity, redesigning the environment and integrating as the last address.

For the artist, nature is the ultimate source of human harmony. His opinion on the sanctity of nature receives support in the resolutions of protection against wear carried out by man and industry. Nunes (2008) considers that the intervention of the higher order of nature in its voluntary restructuring stands out in the theoretical corpus of the artist from the negation of the straight line in 1953, always followed by a viable plan.

The essential step of the eco-naturist house created by Hundertwasser has grass cover reinforced by the humus of the toilet and as the window-tenant trees. These plants store rainwater for use at home. Sewage purification is performed by filtration plants. Figure 5 highlights a ceremony held for planting trees.

Figure 5. Tree Planting Ceremony, Judiciary Square, Washington, November 18.

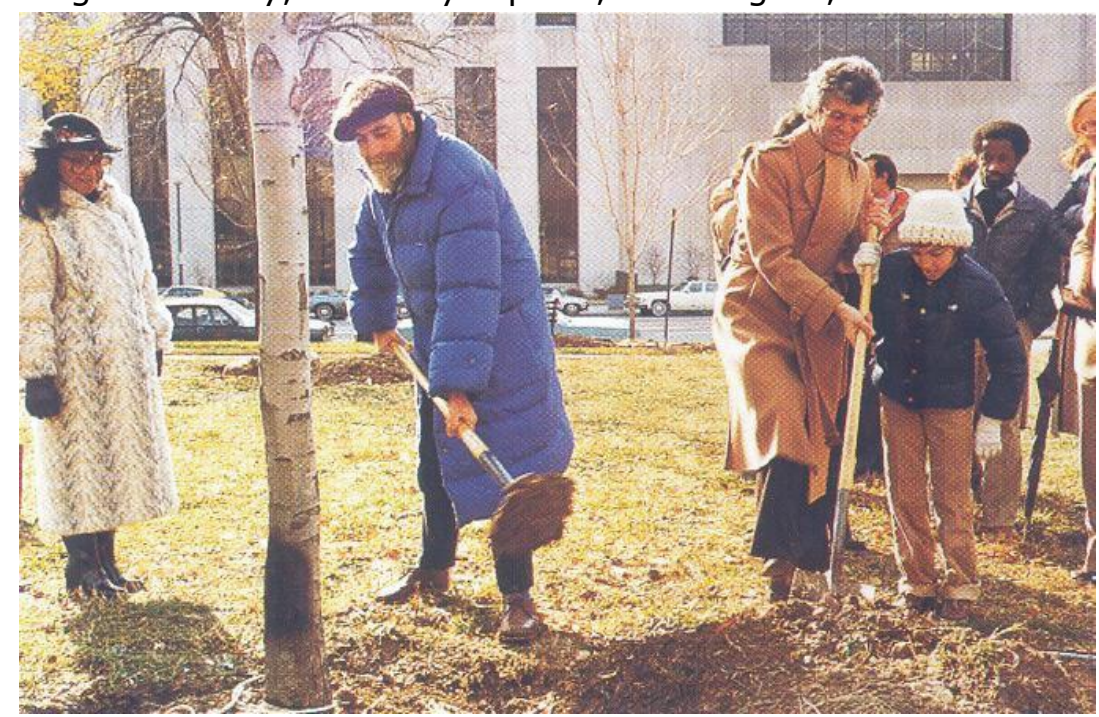

Source: RESTANY, 1999 
This tree planting ceremony symbolizes concern about the continuing threats to nature, the harms of the nuclear force, which led Hundertwasser to explore the Amazon jungle.

Restany (2003) states that Hundertwasser knows the exact charismatic nature of the concepts of his polemic and that his talent is measured by the power of the impact of these ideas on the aesthetic sustainability of individual consciences. Through one look that resides in the retinal persistence of the prospective memory and in the indestructible spiritual force of the luminous gaze on the world that the author invites us to think of fashion as a possibility of behavioral consciousness, a subject that will be treated in the next topic through a brief understanding of slow fashion.

\section{SLOW FASHION}

According to Fletcher and Grose (2011), the core of sustainability is centered on the experience of the connectedness of things, the lived understanding of the countless interrelationships that link economic, material, and sociocultural systems to nature. For the authors, these connections operate at different scales and with different spheres of influence, some with local and direct, others globally.

The concept of sustainability applied to clothing is recent in the history of fashion. It has evolved, and according to theorists such as Lipovestky (1989), since the beginning of fashion in the early fifteenth century, it has been following the transformations of people's lives, comparing it with the zeitgeist spirit of the time.

For Berlim (2012), sustainability has been present in fashion since the 1960s, when the first concerns about the environmental impact caused by the textile industry arose in 
Brazil and the world. As for Barros (2016), the notion of this term begins to be discussed in the 1970s, together with discussions about the environment, and in the mid-1980s, problems related to poverty and social inequality are incorporated into the environmental issue.

However, consuming is a part of our lives, for Lee (2009) the shopping experience is fun and rewarding, especially if we find something soft, beautiful, fashionable and cheap. However, as consumers, we are only part of this chain, because on the other side there are numerous people who participated in the process of building this product. Becoming a conscious consumer doesn 't mean to stop consuming, but rather to balance the quality and quantity that is consumed, thought that meets the emergence of the slow fashion movement.

Slow fashion is defined as a movement that doesn't respond to the rapidity of changes in fashion trends (WATSON; YAN, p. 2013). Much is discussed about the definition and many authors point out that slow fashion is a chain that strengthens the consumer's connection to clothing and its designers also including community values and diversity. So, we can say that it is a movement that values long-term care, quality and thought.

Inspired by slow food that aims to encourage people to return to eating food from their region without the rush of the globalized world, slow fashion emerged according to Kate Fletcher, a consultant and professor of sustainable design at the Centre for Sustainable Fashion, in order to stimulate people to start thinking about the clothing products we consume and what is behind them throughout the production chain in which they are, making people think about the way they are produced and valuing the diversity of traditions and cultures so rich around the world. 
According to Lee (2009), one can say that slow fashion is no longer just a trend and has become a movement, it encompasses issues that are increasingly set in our way of consumption and for this reason, it has become a new direction of the fashion consumer market. The slow has come to make people aware of how important it is to consume the right way.

The slow fashion movement then suggests a break with the values and goals that are based only on the economic growth of the garment industry, encouraging a mode of consumption where less is more - quality over quantity - in addition to redeeming the value of clothes by taking the image of fashion as something disposable, to promote a buying consciousness that must be based on the durability of the pieces and how they are produced (POOKULANGARA; SHEPHARD, 2013).

Slow fashion is also transforming the way clothes are thought, the way people dress them and the relationship between the individual and his style. One of the pillars of the slow is precisely the diversification of styles, to stimulate the people who create the products to always innovate and the consumers to have their own style, to wear clothes that say something about their personality, something that they really like and not something copied from a brand importantly made with products that do not respect ethics and sustainability or even follow the trends that are launched daily by the fast industry.

Unlike the fast fashion movement, slow fashion stimulates designers' creativity by encouraging them to always innovate, developing innovative products that collaborate to the growing demand for products with technology and personality that instead of copying great designs using low-quality materials, seeks the new, the unusual and the sustainable. 
Slow fashion is just the junction we need between sustainable and ethical to find the balance of consumption. It shows not only viable alternatives for reducing the impact on the environment by the products and ways of producing it, including the quality of the material, the durability and the fair price paid by it, but also deals with the valorization of the human being and his work, as well as encouraging creativity and style.

Livni (2012) says that the term "slow fashion" should not be seen as a non-profitable way of doing business, but rather as a way to improve productivity. She further emphasizes that the slow should not be based on profit at the time of sale, on the contrary, the social and ecological gains that generate these new concepts of fashion production thinking in the long run. This new way of fashioning unites creativity, craftsmanship, and technology, with this junction it is possible to create an innovative, sustainable and timeless product.

Fletcher and Grose (2011) highlight the emergence of a new direction of the fashion industry, where the concern with sustainability and the deceleration of consumption, are increasingly present. For the authors, the sustainability process forces the fashion industry to change $[\ldots]$; change the scale and speed of their support structures and incur in them a sense of interconnectivity.

\section{AN ALTERNATIVE BETWEEN 5 (FIVE) MAN'S SKINS AND SLOW MOVEMENT THROUGH A BEHAVIORAL LENS}

Fashion shapes and is shaped by each of the skins of the human being according to the culture, place, and society of each epoch. The human being transforms each of his skins into a means of communicating with the society around him, 
always seeking the best and most perfect appearance for each one of them (WOLF, 2012).

From the dynamics of dissemination of the slow fashion macro-trend, the mapping of information and data to human skins becomes the main process. To get a better insight into the process of change, we, in all cases, have to start with the basic content of social problems. In this project it can be verified through the changes of consumption of the new generation that has been driving the movement of slow fashion as one of the alternatives of the new fashion system, stimulating ecological, social and cultural diversity.

The search for a better society, where well-being and development become present in everyday life since we live in a moment where the consumer seeks a more "correct" consumption. Today we live in a phase of consumption in which the demand of the responsible consumer and citizen is affirmed. It is from these new concerns, of new values that brands are already redirecting their work, developing new products.

Starting from this point and analyzing the vision of Hundertwasser and his work, we can, through the new tendencies of behavior and consumption, identify a relation with the slow fashion movement, where we can identify in each analyzed skin the use of products characteristic of the movement, with focus more specifically on the fifth and last skin. Through this, the relational scheme was developed.

The epidermis - the human being modifies his body driven by social and cultural transformations. In this skin we can make a direct relation with the slow fashion through the analysis of the increase of makeup brands and organic cosmetics, where the consumer started to worry about himself and what he uses on his skin, bringing it to the social context. Tattoos with organic and natural symbols can also be a 
demonstration of the trend reading on the first skin. Making a direct relation with the artist's thought.

Clothing - clothing, as an extension of the body, shows that on one side is the individual and on the other the "role" that he intends to interpret. Dressing is related to the ease of the human being to change its skin. Here we can analyze the growth and development of copyright brands as well as the launch of vegan brands in the market. Many consumers are looking for new and longer-lasting ways to consume.

The house - the dwelling of every human being is constantly influenced by his personal characteristics. The home of each individual is an extension of the body, and we can see a growing market where architecture and design have come together to develop sustainable projects and decoration, as well as new slow alternatives such as the development of organic gardens in homes and condos.

Social identity - the fourth skin has a great connection with the emotional issues of objects and elements that interfere or influence the identity of the user man. Hundertwasser distinguishes and affirms the identity of a people through the symbols that identify it as a nation. We can relate here the lifestyle, habits and customs and all the symbology that identifies this trend. The search for wellness spaces, hybrid spas, outdoor activities, among others.

The global environment and the slow fashion - It is related to sustainability, to live in harmony with the environment. It is to have an ecological conscience, great world trend. The fifth and final one relates the most to the slow fashion movement, and in which we strengthen the relationship between Hunterwasser's theory and its contradiction to Fashion Design. In it, we can encompass all other skins, and show that the behavior happens through everything that the individual consumes and his way of life. 


\section{CONCLUSION}

This work aimed to relate Hundertwasser's Theory of 5 skins, sustainability, and the slow fashion movement. It can be observed that the Hundertwasser theory contributes to the understanding of how the relation of the individual to his surroundings occurs, from his own body to the planet as a whole.

The slow fashion movement is directly related to Hundertwasser's theory mainly from the analysis of the fifth skin where a great behavioral tendency is observed in the search for integral ecological consciousness, strengthening the idea of evolution from fashion design to more conscious consumption.

From this article, new studies on the theme will be developed in the search for a behavioral referential for the new generations, by reading the slow fashion movement and its contribution to the construction of a new fashion system, with a sustainable vision and practices conscious of production and consumption.

\section{REFERENCES}

BERLIM, Lilyan. Moda e Sustentabilidade: uma reflexão necessária. São Paulo: Estação das Letras e Cores Editora, 2012.

CALDAS, Dario. Observatório de Sinais: teoria e prática da pesquisa de tendências. Rio de Janeiro: Senac Rio, 2004.

CALDAS, Dario. Vestígios do Futuro: estilos de vida, consumo e tendência. 1. Ed São Paulo, 2017.

CASTILHO, Káthia. Moda e Linguagem. São Paulo: Anhembi Morumbi, 2004.

ERNER, Guillaume. Sociologia das Tendências. Coleção GGmoda, 2015.

FLETCHER, Kate; GROSE, Lynda. Moda \& Sustentabilidade: design para mudança. São Paulo: Editora Senac São Paulo, 2011.

LEE, Matilda. ECO CHIC:O guia de moda ética para a consumidora consciente. 1.ed.São Paulo: Larousse, 2009. 
LIPOVETSKY, Gilles. O império do efêmero: a moda e seu destino nas sociedades modernas. São Paulo: Companhia das Letras, 1989.

LOBO, Suelem Costa. A moda na construção das 5 (cinco) peles do ser humano. São José, 2012. Disponível em: https://prezi.com/z3k2uj0hu3gc/a-moda-na-construcao-das-5cinco-peles-do-ser-humano/. Acesso em: 26 jun. 2015.

NUNES, Katia. Hundertwasser: Arte e Ecologia. Trabalho de Conclusão do Curso de Licenciatura e Artes Plásticas da Universidade do Estado de Santa Catarina. Florianópolis, 2008.

OLIVEIRA, Marcio Romeu Ribas de. \#Hunderwassercorpoimensoeducador. PPGE/ME FURB. Agosto, 2008.

POOKULANGARA, Sanjukta; SHEPHARD, Arlesa. Slow fashion movement: understanding consumer perceptions - na exploratory study. Journal of retailing and consumer services. EUA: v. 20, n. 2, p. 200-206, janeiro 2013.

RESTANY, Pierre. O Poder da Arte Hundertwasser - O Pintor-rei das Cinco Peles. Koln: Taschen, 1999.

SILVA, Eric da Costa. Das cores e das peles - A construção de uma identidade múltipla. Brasília, 2013.

VEJGAARD, H. Anatomy of a trend. Nee York: McGraw-Hill, 2008. WATSON, Maegan; YAN, Ruoh-Nan. An exploratory study of the decision processes of fast versus slow fashion consumers. Jornal of fashion marketing and management. EUA: v.17, n. 2, p. 141159, setembro 2013. 